\title{
INTRODUCTIONS AND ACKNOWLEDGEMENTS
}

\section{Years of the Geneva Association}

\author{
by Claude Bébéar*
}

Insurance makes it possible to face the risks that are inherent in any human endeavor connected with the creation of wealth. For this reason, insurance has always been a faithful indicator of the level of economic development. The insurers' business is to cover risks and manage assets. In a world that is changing rapidly in every area, they must rethink the size and structure of their organization and strengthen the professionalism of their workforce. After all, these are the essential features of any service-oriented activity. The future of our profession depends on transforming external constraints into development opportunities. These constraints include:

- the technological revolution, especially in information systems

- the globalization of the economy and the emergence of new players (particularly Asian countries)

- the aging of the population in the developed countries

- deregulation and less involvement on the part of public institutions

- the changing notion of liability

- better-informed consumers who are, as a result, more difficult to please and more demanding

- the trend toward internationalization and concentration in the insurance industry

- diversification in distribution channels

- the increasing demand on the part of shareholders for full disclosure and a high return on their investment

* Chairman of the AXA Group and Vice President of the Geneva Association 
The founders of the Geneva Association created a club for insurance company CEOs 25 years ago, to enable the latter to incorporate up-to-date economic research into their strategic planning.

With the help of highly talented economists and industry professionals, the Association has consistently supplied its members with comprehensive surveys on trends that have had a great impact on our profession over the years.

Originally European, now global in scope, the Association is widely acknowledged as one of the driving forces servicing a profession without which today's modern economy could not function. The Association deserves praise for its foresight. 